\title{
INDEX TO Volume $22(2004)$
}

ArTicles

DARD, Olivier. Fourastié avant Fourastié: la construction d'une légitimité d'expert (Vol. 22, No. 1, p. 1)

GEMIE, Sharif. An Extremism of the Center? Jean-Pierre Chevènement, French Presidential Candidate, 2002 (Vol. 22, No. 1, p. 76)

GRÉMION, Catherine. Mixité sociale et habitat des familles immigrées: perspective historique (Vol. 22, No. 3, p. 76)

JOSSELIN, Daphne. Between Europe and a Hard Place: French Financial Diplomacy from 1995 to 2002 (Vol. 22, No. 1, p. 57)

OPELLO, Katherine A. R. Elections: Explaining the Timing of the French Socialist Party's Gender-Based Quota (Vol. 22, No. 3, p. 25)

PRICE, Sally. Michel Leiris, French Anthropology, and a Side Trip to the Antilles (Vol. 22, No. 1, p. 23)

REID, Donald. From Ravensbruck to Algiers and Noisy-le-Grand: The Dialogues with Deportation of Germaine Tillion and Geneviève de GaulleAnthonioz (Vol. 22, No. 3, p. 1)

SHIELDS, James G. An Enigma Still: Poujadism Fifty Years On (Vol. 22, No. 1, p. 36)

VALLET, Élisabeth. L'Autonomie corse face à l'individualisme de la République (Vol. 22, No. 3, p. 51)

Dossier: French-AmericAn Relations in CRISIS

KUISEL, Richard. What Do the French Think of the US? The Deteriorating Image of the United States, 2000-2004 (Vol. 22, No. 3, p. 91)

COGAN, Charles. The Iraq Crisis and France: Heaven-Sent Opportunity or Problem from Hell? (Vol. 22, No. 3, p. 120)

Dossier: The Stasi Commission and the Headscarf LaW

BAUBÉROT, Jean. La commission Stasi vue par l'un de ses membres (Vol. 22, No. 3, p. 135)

WEIL, Patrick. Lifting the Veil (Vol. 22, No. 3, p. 142) 
Events and Debates: La France Qui Tombe? / Le Monde Qui Tombe?

MEUNIER, Sophie. Free-Falling France or Free-Trading France? (Vol. 22, No. 1, p. 98)

BENSON, Rodney. La Fin du Monde? Tradition and Change in the French Press (Vol. 22, No. 1, p. 108)

GRÉMION, Pierre. Premières leçons d'un audit sauvage (Vol. 22, No. 1, p. 127)

\section{Events AND Debates}

JOSPIN, Lionel. The Relationship Between France and the United States: Reflections for an American Audience (Vol. 22, No. 2, p. 118)

Special Issue: Alain Corbin and the Writing of History

BEAUJOUR, Michel. Le style de Corbin (Vol. 22, No. 2, p. 79)

CORBIN, Alain. A Reply (Vol. 22, No. 2, p. 109)

GERSON, Stéphane. L'impossible présence de l'historien (Vol. 22, No. 2, p. 91)

GOLDHAMMER, Arthur. Torpor and Rage: From Haute-Frêne to Hautefaye (Vol. 22, No. 2, p. 68)

KALIFA, Dominique. L'expérience, le désir et l'histoire: Alain Corbin ou le "tournant culturel" (Vol. 22, No. 2, p. 14)

PERROT, Michelle. Alain Corbin et l'histoire des femmes (Vol. 22, No. 2, p. 44)

PROCHASSON, Christophe. La politique comme "culture sensible": Alain Corbin face à l'histoire politique (Vol. 22, No. 2, p. 56)

SAADA, Emmanuelle. L'historien, l'ethnographe et l'employé de l'état civil (Vol. 22, No. 2, p. 26)

\section{REview EssAY}

BERENSON, Edward. Making a Colonial Culture? Empire and the French Republic, 1880-1940 (Vol. 22, No. 2, p. 127)

Book Reviews

CARTIER, Marie. La Dactylographie et l'expéditionnaire: Histoire des employés de bureau (1890-1930) by Dephine Gardey (Vol. 22, No. 1, p. 143)

DOWNS, Laura. Simone Weil by Francine du Plessix Gray (Vol. 22, No. 2, p. 150)

FERGUSON, Priscilla Parkhurst. Paris: Capital of the World, trans. Arthur Goldhammer, by Patrice Higonnet (Vol. 22, No. 3, p. 150)

IRELAND, John. La Naissance du phénomène Sartre: Raisons d'un success 19381945 by Ingrid Galster (Vol. 22, No. 1, p. 149) 
MATHESON, Tamara Chaplin. The de Gaulle Presidency and the Media: Statism and Public Communications by Jean K. Chalaby (Vol. 22, No. 3, p. 161)

ROOS, Jane Mayo. Paris in Despair: Art and Everyday Life under Siege 1870-71 by Hollis Clayson (Vol. 22, No. 3, p. 153)

SHULL, Tad. Between Montmartre and the Mudd Club: Popular Music and the Avant-Garde by Bernard Gendron (Vol. 22, No. 1, p. 146)

TONNELAT, Stéphane. The Glass State: The Technology of the Spectacle, Paris, 1981-1998 by Annette Fierro (Vol. 22, No. 2, p. 154)

SCOTT, Joan. Fausse Route by Elisabeth Badinter (Vol. 22, No. 2, p. 157)

WALZ, Robin. Genre, Myth, and Convention in the French Cinema, 1929-1939 by Colin Crisp (Vol. 22, No. 3, p. 158)

INDEX OF BOOKS REvIEWED

BADINTER, Elisabeth. Fausse Route reviewed by Joan Scott (Vol. 22, No. 2, p. 157)

CHALABY, Jean K. The de Gaulle Presidency and the Media: Statism and Public Communications reviewed by Tamara Chaplin Matheson (Vol. 22, No. 3, p. 161)

CLAYSON, Hollis. Paris in Despair: Art and Everyday Life under Siege 1870-71

Reviewed by Jane Mayo Roos (Vol. 22, No. 3, p. 153)

CRISP, Colin. Genre, Myth, and Convention in the French Cinema, 1929-1939 reviewed by Robin Walz (Vol. 22, No. 3, p. 158)

DU PLESSIS GRAY, Francine. Simone Weil reviewed by Laura Downs (Vol. 22, No. 2, p. 150)

FIERRO, Annette. The Glass State: The Technology of the Spectacle, Paris, 19811998 reviewed by Stéphane Tonnelat (Vol. 22, No. 2, p. 154)

GALSTER, Ingrid. La Naissance du phénomène Sartre: Raisons d'un success 1938-1945 reviewed by John Ireland (Vol. 22, No. 1, p. 149)

GARDEY, Delphine. La Dactylographie et l'expéditionnaire: Histoire des employés de bureau (1890-1930) reviewed by Marie Cartier (Vol. 22, No. 1, p. 143)

GENDRON, Bernard. Between Montmartre and the Mudd Club: Popular Music and the Avant-Garde reviewed by Tad Shull (Vol. 22, No. 1, p. 146)

HIGONNET, Patrice. Paris: Capital of the World, trans. Arthur Goldhammer, reviewed by Priscilla Parkhurst Ferguson (Vol. 22, No. 3, p. 150) 